\title{
Видовий склад та рівень обсіменіння мікроорганізмами перитонеального ексудату за умов гострої крововтрати, уск.ладненої ішемією-реперфузією кінцівки
}

\begin{abstract}
Мета роботи: з’ясувати видовий склад та рівень обсіменіння мікроорганізмами перитонеального ексудату за умов гострої крововтрати, ускладненої ішемією-реперфузією кінцівки.

Матеріали і методи. Експерименти виконано на 96 нелінійних щурах-самцях масою 180-200 г. Усіх тварин поділили на чотири групи: контрольну та три дослідних. Під тіопентал-натрієвим наркозом у першій дослідній групі моделювали ішеміюреперфузію кінцівки, у другій - гостру крововтрату, у третій - ці ушкодження поєднували. Через 1 і 2 години, а також через 1, 7 i 14 діб в умовах тіопентал-натрієвого наркозу піддослідних тварин виводили з експерименту методом тотального кровопускання з серця. Матеріал (мазок з очеревини) забирали з латеральних частин черевної порожнини одноразовим тампоном фірм Eurotubo (Іспанія). Дослідження наявної мікрофлори проводили загальноприйнятим бактеріологічним методом.

Результати досліджень та їх обговорення. При моделюванні ішемії-реперфузії кінцівки, гострої крововтрати та їх поєднання має місце транслокація мікроорганізмів. Вона була найбільшою при моделюванні гострої крововтрати, ускладненої ішемією-реперфузією кінцівки, найменшою - при моделюванні лише ішемії-реперфузії кінцівки, про що свідчать показники бактеріального обсіменіння перитонеального ексудату, зустрічальності (Pi) та дані щодо постійності виділення культур ентеробактерій у різних групах. Першими й у вищих концентраціях колонізували перитонеальний простір популяції кишкових паличок, про що свідчив найвищий показник зустрічальності Pi для E. coli в усіх групах дослідних тварин, порівняно з іншими виділеними мікроорганізмами. Показники постійності виділення бактерій були найвищими у тварин із поєднанням ішемії-реперфузії кінцівки та гострої крововтрати. Збільшення проникності кишкової стінки із транслокацією кишкової мікрофлори є чутливим індикатором ішемічнореперфузійного синдрому та гострої крововтрати, що слід враховувати в розробці заходів інтенсивної терапії.
\end{abstract}

Ключові слова: тонка кишка; крововтрата; ішемія-реперфузія кінцівки; транслокація мікрофлори.

Постановка проблеми і аналіз останніх досліджень та публікацій. Застосування кровоспинних джгутів стало невід’ємною частиною порятунку життя поранених і постраждалих із масивною зовнішньою кровотечею [1]. За цих умов тривалість накладання джгута на кінцівку не повинна перевищувати дві години.

За результатами досліджень ряду авторів, повне знекровлення кінцівки впродовж двох годин може зумовити пошкодження нервів, судин і м'язів [2], які поглиблюються після реперфузії кінцівки насамперед завдяки утворенню активних форм оксигену, посилення процесів ліпідної пероксидації [3]. Реваскуляризація призводить до поглиблення порушень в ішемізованій кінцівці і зумовлює надходження ендотоксинів у системний кровотік. Останні, у свою чергу, ініціюють такі системні порушення, як метаболічний ацидоз, гіперкаліємія, міоглобінемія, активація процесів ПОЛ та зниження антиоксидантного захисту в тканинах та органах, віддалених від місця безпосереднього ураження [4-6].

На сьогодні доведено, що порушення, спричинені ішемією-реперфузією кінцівки, призводять до порушень функціонального стану внутрішніх органів: печінки, нирок, легень і за умов одночасної гострої крововтрати чи механічної травми по- глиблюють розвиток поліорганної недостатності $[7,8]$.

Однак роль ішемії-реперфузії кінцівки та гострої крововтрати в порушеннях функціонального стану тонкої кишки вивчена недостатньо. Зокрема, немає даних щодо проникності стінки тонкої кишки до кишкової мікрофлори, що є характерною особливістю тяжкої травми [9].

Мета роботи: з'ясувати видовий склад та рівень обсіменіння мікроорганізмами перитонеального ексудату за умов гострої крововтрати, ускладненої ішемією-реперфузією кінцівки.

Матеріли і методи. В експериментах використано 96 нелінійних щурів-самців масою 180200 г, яких розділили на чотири групи: контрольну та три дослідних (по 6 щурів у групі). Усі втручання виконано під тіопентал-натрієвим наркозом У дозі 40 мг•кг-1. У першій дослідній групі тваринам моделювали ішемію-реперфузію кінцівки. 3 цією метою на ліву лапку проксимально накладали смужку еластичного джгута “SWAT-T” (США) шириною 10 мм, який повністю припиняв кровотік впродовж 120 хв. У другій дослідній групі шляхом пересікання стегнової вени моделювали гостру крововтрату (20 \% від об’єму циркулюючої крові). У третій дослідній групі ці пошкоджен- 
ня поєднували. В контрольній групі тварин тільки вводили в наркоз, застосовуючи еквівалентну дозу тіопенталу натрію.

Через 1 і 2 години, а також через 1, 7 і 14 діб в умовах тіопентал-натрієвого наркозу піддослідних тварин виводили з експерименту методом тотального кровопускання з серця. Матеріал (мазок з очеревини) забирали з латеральних частин черевної порожнини одноразовим тампоном фірм Eurotubo (Іспанія). Дослідження наявної мікрофлори проводили загальноприйнятим бактеріологічним методом. Для визначення факультативно анаеробної флори біоматеріал відразу після забору вносили в цукровий м'ясо-пептонний бульйон, облігатної анаеробної мікрофлори в тіогліколеве середовище. Матеріал впродовж години доставляли в лабораторію. Для отримання ізольованих колоній мікроорганізмів для кількісного підрахунку та подальшої ідентифікації перитонеальний ексудат засівали методом штрихів на наступні живильні середовища: цукровий кров'яний МПА (для вирощування анаеробів, стрептококів та вивчення гемолітичних властивостей бактерій), жовтково-сольовий агар (для виділення стафілококів), середовище Ендо (для визначення ентеробактерій), біфідум-середовище та лактоагар для росту біфідо- й лактобактерій. Через 24-96 годин інкубації (для визначення факультативних анаеробів), 5 діб (для облігатних анаеробів) при температурі $37{ }^{\circ} \mathrm{C}$ підраховували кількість колоній, що вирос- ли (КУО/мл перитонеального ексудату). Визначали видовий склад мікроорганізмів, частоту їх виявлення (Pi). Ідентифікацію виділених бактерій проводили за загальновизнаними методиками [10] та згідно з класифікацією Бергі (1997р.), використовуючи відповідні тест-системи MIKROLA-TEST (“ERBA-Lachema Diagnostika”, Чеська Республіка).

Під час роботи з лабораторними тваринами дотримувались міжнародних вимог про гуманне поводження з тваринами відповідно до правил “Європейської конвенції захисту хребетних тварин, яких використовують $з$ експериментальною та іншою науковою метою” (European Convention, 1984).

Результати досліджень та їх обговорення. У результаті мікробіологічного дослідження ексудату, взятого з черевної порожнини дослідних тварин, після моделювання та розвитку реперфузійноішемічного пошкодження (перша дослідна група), після гострої крововтрати (друга дослідна група) та після гострої крововтрати, ускладненої ішемією-реперфузією кінцівки (третя дослідна група), було ідентифіковано штами факультативних анаеробних бактерій, які віднесені до представників нормальної мікрофлори кишок. Проте з перитонеального простору щурів контрольної групи не висіяно жодних мікроорганізмів. Тому аналіз бактеріологічних досліджень проводили, порівнюючи результати, отримані у дослідних групах (табл. 1).

Таблиця 1. Спектр мікроорганізмів, їх щільність колонізації очеревини (КУО-мл $\left.{ }^{-1}\right)$ та частота виявлення видів (Рі, \%) після гострої крововтрати, ускладненої ішемією-реперфузією кінцівки

\begin{tabular}{|c|c|c|c|c|c|c|c|c|c|}
\hline \multirow{3}{*}{$\begin{array}{c}\text { Термін } \\
\text { реперфу- } \\
\text { зійного } \\
\text { періоду }\end{array}$} & \multirow{3}{*}{$\begin{array}{c}\text { Мікро- } \\
\text { організм }\end{array}$} & \multirow{2}{*}{\multicolumn{2}{|c|}{$\begin{array}{l}\text { Контрольна } \\
\text { група, }(\mathrm{n}=6)\end{array}$}} & \multicolumn{6}{|c|}{ Дослідна група тварин } \\
\hline & & & & \multicolumn{2}{|c|}{ перша, $(\mathrm{n}=6)$} & \multicolumn{2}{|c|}{ друга, $(\mathrm{n}=6)$} & \multicolumn{2}{|c|}{ третя, $(\mathrm{n}=6)$} \\
\hline & & $\begin{array}{c}\text { щільність } \\
\text { колонізації }\end{array}$ & $\mathrm{Pi}$ & $\begin{array}{c}\text { щільність } \\
\text { колонізації }\end{array}$ & $\mathrm{Pi}$ & $\begin{array}{c}\text { щільність } \\
\text { колонізації }\end{array}$ & $\mathrm{Pi}$ & $\begin{array}{c}\text { щільність } \\
\text { колонізації }\end{array}$ & $\mathrm{Pi}$ \\
\hline 1 год & E.coli & 0 & 0 & 0 & 0 & $5,6 \times 10^{2}$ & 66,7 & $8,4 \times 10^{2}$ & 100 \\
\hline 2 год & E.coli & 0 & 0 & $2,4 \times 10^{2}$ & 83,3 & $3,8 \times 10^{3}$ & 100 & $7,1 \times 10^{3}$ & 100 \\
\hline \multirow[t]{3}{*}{1 доба } & E.coli & 0 & 0 & $3,1 \times 10^{3}$ & 83,3 & $6,3 \times 10^{4}$ & 100 & $5,2 \times 10^{6}$ & 100 \\
\hline & Klebsiella spp. & 0 & 0 & 13 & 33,3 & $2,4 \times 10^{2}$ & 50,0 & $2,6 \times 10^{3}$ & 66,7 \\
\hline & P. mirabilis & 0 & 0 & 0 & 0 & $1,8 \times 10^{2}$ & 33,3 & $2,2 \times 10^{2}$ & 33,3 \\
\hline \multirow[t]{3}{*}{7 доба } & E.coli & 0 & 0 & 0 & 66,7 & $3,5 \times 10^{3}$ & 83,3 & $3,8 \times 10^{4}$ & 83,3 \\
\hline & Klebsiella spp. & 0 & 0 & 0 & 0 & 84 & 16,7 & $3,9 \times 10^{2}$ & 50,0 \\
\hline & P. mirabilis & 0 & 0 & 0 & 0 & 6 & 16,7 & 24 & 16,7 \\
\hline \multirow[t]{2}{*}{14 доба } & E.coli & 0 & 0 & 0 & 0 & $3,1 \times 10^{2}$ & 50,0 & $5,6 \times 10^{3}$ & 66,7 \\
\hline & Klebsiella spp. & 0 & 0 & 0 & 0 & 0 & 0 & 37 & 16,7 \\
\hline
\end{tabular}


Варто відмітити, що щільність колонізації бактеріями черевної порожнини була найвищою у третій дослідній групі щурів, у якій моделювали ішеміюреперфузію кінцівки на тлі гострої крововтрати.

Через годину від початку проведення експерименту в дослідних групах щурів, яким було змодельовано гостру крововтрату та гостру крововтрату, ускладнену ішемією-реперфузією кінцівки 3 перитонеального простору, були висіяні штами E. coli. Це рухливі грамнегативні палички знаходяться в тонкій кишці у високій концентрації, завдяки чому вони першими можуть транслокуватися з просвіту шлунково-кишкового тракту в черевну порожнину. Причому середня щільність колонізації кишковими паличками очеревини була дещо вищою у третій дослідній групі лабораторних тварин і становила $8,4 \cdot 10^{2} \mathrm{KУО/мл.} \mathrm{У} \mathrm{під-}$ дослідних тварин першої дослідної групи станом на першу годину після початку розвитку реперфузійного синдрому очеревина залишалася стерильною. Найвищу щільність колонізації виявили на першу добу в кожній із дослідних груп порівняно з іншими термінами реперфузії.

Від тварин першої дослідної групи висіяно 16 штамів факультативних анаеробних паличок. Всі вони віднесені до родини ентеробактерій. Після першої години проведення експерименту явища транслокації представників кишкового мікробіому не спостерігали, очеревина залишалася стерильною. У другу годину після початку досліду виділено монокультури кишкових паличок $(\mathrm{Pi}=83,3$ \%), які колонізували очеревину зі щільністю $2,4 \cdot 10^{2} \mathrm{KУO} \cdot{ }^{-1} \pi^{-1}$ В одного із щурів цієї групи мікроорганізмів не виявлено. Через добу з ексудату черевної порожнини висіяно штами грамнегативних ентеробактерій, середня щільність яких зросла на порядок і становила $1,6 \cdot 10^{3} \mathrm{KУO} \mathrm{м}^{-1}$. У 4-х щурів цієї групи E. coli були виділені в монокультурі, у трьох тварин - в асоціації з культурами K. pneumoniae. Варто відмітити, що концентрація кишкових паличок була значно вищою від щільності колонізації очеревини клебсієлами. Таке переважання, можливо, пояснюється тим, що на відміну від E. coli, клебсієли - нерухомі бактерії, а тому їх транслокація відбувалася повільніше. Отже, через 1 добу від початку експерименту транслокація бактерій з тонкої кишки відбувалася у 83, 3 \% дослідних тварин. На сьому добу реперфузійного періоду і через 2 тижні мікроорганізмів у перитонеальному просторі не було знайдено.

Від тварин другої групи висіяно 29 штамів ентеробактерій, які належали до наступних видів: E. coli, K. aerogenes, K. pneumoniae, P. mirabilis. Після першої години гострої крововтрати від до- слідних щурів цієї групи (Pi=83,3 \%) були виділені монокультури кишкової палички. Вони колонізу-

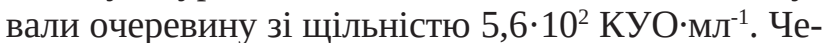
рез 2 години - штами E. coli були висіяні від усіх тварин (Pi=100 \%), а щільність колонізації зросла на порядок і становила $3,8 \cdot 10^{3} \mathrm{KУO}^{-} \mathrm{M}^{-1}$, що в 15,8 раза вище, ніж за умови моделювання лише ішеміїреперфузії кінцівки. На першу добу видовий склад черевного ексудату став ширшим, проте кишкові палички переважали. Показники їх щільності колонізації були найвищими $\left(6,3 \cdot 10^{4} \mathrm{KУO} \cdot \mathrm{Mл}^{-1}\right)$. Варто відмітити, що культури E. coli були виділені в асоціації з іншими ентеробактеріями, щільність колонізації яких була набагато меншою: густина Klebsiella spp. становила 2,4·10 ${ }^{2}$ КУО мл $^{-1}$, P. mirabilis - $1,8 \cdot 10^{2} \mathrm{KУO}^{\prime} \mathrm{M}^{-1}$. Надалі показники щільності колонізації знижувалися, і кількість тварин із крововтратою, у яких спостерігали явище транслокації мікроорганізмів, також зменшувалося. На сьому добу бактерї колонізували очеревину зі щільністю $1,2 \cdot 10^{3} \mathrm{KУO} \cdot \mathrm{Mл}^{-1}(\mathrm{Pi}=83,3 \%)$, на 14 -ту $-3,1 \cdot 10^{2} \mathrm{KУO} \mathrm{M}^{-1}(\mathrm{Pi}=50,0 \%)$.

Від тварин третьої дослідної групи висіяно 32 культури мікроорганізмів, спектр яких був подібним до тих, які ідентифікували в другій групі дослідних щурів. Варто відмітити, що явище бактеріальної транслокації з тонкої кишки спостерігали уже через годину після початку досліду у всіх дослідних щурів ( $\mathrm{Pi}=100 \%)$. У цей термін реперфузії кишкові палички були виділені в монокультурах, як і в попередній групі тварин, проте густина яких була дещо вищою, ніж після гострої крововтрати, й становила $8,4 \cdot 10^{2} \mathrm{KУО}^{-\mathrm{M}^{-1}}$. Через 2 години реперфузійного періоду 3 крововтратою транслокація E. coli зросла і щільність колонізації кишковими паличками очеревини збільшилася на порядок $\left(7,1 \cdot 10^{3} \mathrm{KУO} \cdot \mathrm{M}^{-1}\right)$. Після 24 годин 3 моменту моделювання ішемії-реперфузії кінцівки в поєднанні з гострою крововтратою густина ентеробактерій у перитонеальному ексудаті зросла до $1,7 \cdot 10^{6} \mathrm{KУO} \cdot л^{-1}$. Порівняно 3 даними, отриманими в цій групі в інші терміни експерименту, станом на першу добу цей показник виявився найвищим. Водночас порівняно з показниками щільності колонізації в першій і другій групах дослідних тварин, визначеними у цей термін, густина бактерій у третій групі щурів була також найбільшою (вища на 3 і на 2 порядки відповідно). 3 очеревини висівали штами E. coli, K. pneumoniae, $K$. aerogenes, K. pneumoniae, $P$. mirabilis в двокомпонентних асоціаціях. Хоча популяції кишкових паличок колонізували перитонеальний простір 3 найвищою щільністю $\left(5,2 \cdot 10^{6} \mathrm{KУO}^{-\mathrm{M}^{-1}}\right)$, проте монокультур E. coli не виділяли. Щільність коло- 
нізації Klebsiella spp. становила 2,6 $10^{3} \mathrm{KУO} \cdot$ мл $^{-1}$ $(\mathrm{Pi}=66,7)$, P. mirabilis $-2,2 \cdot 10^{2} \mathrm{KУO} \cdot \mathrm{M}^{-1}(\mathrm{Pi}=33,3)$. На сьому добу кількість мікроорганізмів у перитонеальному ексудаті знизилася на 2 порядки й дорівнювала 3,8·10 $\mathrm{KУO}^{4}$ мл $^{-1}$. Причому зменшилося видове різноманіття ентеробактерій: не висівали протеїв, з'явилися монокультури кишкових паличок $(\mathrm{Pi}=83,3$ \%). Через 14 діб кількість щурів, у яких спостерігали явище бактеріальної транслокації зменшилося. Показники щільності колонізації мікроорганізмами очеревини знизилися також, проте залишалися вищими, порівняно з даними досліду, отриманими після першої години проведеного експерименту $\left(2,8 \cdot 10^{3} \mathrm{KУО}\right.$ мл $^{-1}$ проти 8,4·10 КУО'мл ${ }^{-1}$ відповідно).

Результати проведених досліджень показали, що при моделюванні ішемії-реперфузії кінцівки, гострої крововтрати та їх поєднання має місце транслокація мікроорганізмів. Вона була найбільшою при моделюванні гострої крововтрати, ускладненої ішемією-реперфузією кінцівки, найменшою - при моделюванні лише ішемії-реперфузії кінцівки, про що свідчать показники бактеріального обсіменіння перитонеального ексудату, зустрічальності (Pi) та дані щодо постійності виділення культур ентеробактерій у різних групах. Першими й у вищих концентраціях колонізували перитонеальний простір популяції кишкових паличок, про що свідчив найвищий показник зустрічальності Pi для E. coli в усіх групах дослідних тварин, порівняно з іншими виділеними мікроорганізмами. Показники постійності виділення бактерій були найвищими у тварин з поєднанням ішемії-реперфузії кінцівки та гострої крововтрати. У всіх тварин цієї дослідної групи висіяні мікроорганізми на противагу групі тварин, в якій моделювали лише ішемію-реперфузією кінцівки, де окремі взяті зразки були стерильними. Очевидно, внаслідок сумації патогенних механізмів ішемії-реперфузії кінцівки та гострої крововтрати зростає проникність стінки тонкої кишки для представників кишкової мікрофлори. Ці результати підтверджують дані інших авторів, в яких доведено, що посилення транслокації мікрофлори пропорційне тяжкості травми [9] і пов'язане з проапоптичним впливом на епітелій тонкої кишки прозапальних цитокінів. Можна припустити, що збільшення проникності кишкової стінки із транслокацією кишкової мікрофлори є чутливим індикатором ішемічно-реперфузійного синдрому та гострої крововтрати, що слід враховувати в розробці заходів інтенсивної терапії.

Висновки. 1. Моделювання ішемії-реперфузії кінцівки, гострої крововтрати та їх поєднання викликає транслокацію кишкових бактерій у черевну порожнину з максимумом через 1 добу експерименту.

2. За умов гострої крововтрати, ускладненої ішемією-реперфузією кінцівки, порушення є найбільшими, що проявляються зростанням видового складу та щільності колонізації очеревини бактеріями.

Перспективи подальших досліджень. У перспективі на розробленій експериментальній моделі доцільно провести скринінг ефективності різних лікарських засобів для підвищення бар'єрної функції тонкої кишки за умов гострої крововтрати, ускладненої ішемією-реперфузією кінцівки.

\section{СПИСОК ЛІТЕРАТУРИ}

1. An evidence-based prehospital guideline for external hemorrhage control: American College of Surgeons Committee on Trauma / E. M. Bulger, D. Snyder, K. Schoelles [et al.] // Prehosp. Emerg. Care. - 2014. - Vol. 18 (2). - P. 163-173.

2. Clasper J. C. Limb complications following pre-hospital tourniquet use / J. C. Clasper, K. V. Brown, P. Hill // J. R. Army Med. Corps. - 2009. - Vol. 155 (3). - P. 200-202.

3. Телевяк А. Т. Динаміка показників перекисного окислення ліпідів та антиоксидантного захисту в м’язовій тканині задніх кінцівок щурів при розвитку ішемічно-реперфузійного синдрому (експериментальне дослідження) / А. Т. Телевяк // Здобутки клініч. і експерим. медицини. - 2018. - № 3 (35). C. 132-139.

4. Morsey H. Patients with critical ischemia of the lower limb are at risk of developing kidney dysfunction / H. Morsey, M. Aslam, N. Standfield // Am. J. Surg. - 2003. - Vol. 185. - P. 360-363.

5. Comparison of changes in markers of muscle damage induced by eccentric exercise and ischemia/reperfusion / Q. S. Su,

J. G. Zhang, R. Dong [et al.] // Scand. J. Med. Sci. Sports. - 2010. - Vol. 20 (5). - P. 748-756.

6. Максимів Р. В. Динаміка балансу антиоксидантно-прооксидантних механізмів у внутрішніх органах під впливом артеріального джгута і реперфузії кінцівки / Р. В. Максимів, А. А. Гудима, В. М. Сидоренко // Шпитальна хірургія. Журнал імені Л. Я. Ковальчука. - 2017. - № 1. - С. 37-44.

7. Кузьмінський I. В. Особливості жовчовидільної функції печінки в умовах ішемічно-реперфузійного синдрому кінцівок, закритої травми органів черевної порожнини, ускладненої масивною крововтратою / І. В. Кузьмінський // Актуальні проблеми транспортної медицини. - 2018. - № 4 (54). C. $148-158$.

8. Influence of two-hour tourniquets ischemia of limb and acute blood loss on systemic disorders of the body in the reperfusion period (experimental study) / I. I. Horban, A. A. Hudyma, R. V. Maksymiv, I. V. Antonyshyn// Wiad. Lek. - 2020. - LXXIII, Issue 7. - P. 1330-1333. DOI: 10.36740/WLek202007104. 
9. Видовий склад та рівень обсіменіння мікроорганізмами перитонеального ексудату в ранній період після моделювання скелетної, черепно-мозкової та поєднаної травм / Р. Д. Левчук, О. В. Покришко, Р. М. Борис, Т. І. Дзецюх // Актуальні питання транспортної медицини. - 2015. - № 4, т. 2 (42-2). - C. $148-155$.

\section{REFERENCES}

1. Bulger, E.M., Snyder, D., Schoelles, K., Gotschall, C., Dawson, D., Lang, E., ..., McSwain, N. Jr. (2014). An evidence-based prehospital guideline for external hemorrhage control: American College of Surgeons Committee on Trauma. Prehosp. Emerg. Care., 18 (2), 163-173.

2. Clasper, J.C., Brown, K.V., \& Hill, P. (2009). Limb complications following pre-hospital tourniquet use. J. R. Army Med. Corps., 155 (3), 200-202.

3. Televiak, A.T. (2018). Dynamika pokaznykiv perekysnoho okyslennia lipidiv ta antyoksydantnoho zakhystu v miazovii tkanyni zadnikh kintsivok shchuriv pry rozvytku ishemichno-reperfuziinoho syndromu (eksperymentalne doslidzhennia) [The dynamic of indicators of lipid peroxidation and antioxidant protection in muscle tissue of the hind limbs of the rats in development of the ischemic-reperfusion syndrome (experimental study)]. Zdobutky klinich. i eksperym. Medytsyny - Achievements of Clinical and Experimental Medicine, 3 (35), 132-139 [in Ukrainian].

4. Morsey, H., Aslam, M., \& Standfield, N. (2003). Patients with critical ischemia of the lower limb are at risk of developing kidney dysfunction. Am. J. Surg., 185, 360-363.

5. Chen, N., Zhang, J.G., Han, C.L., \& Meng, F.G. (2010). Comparison of changes in markers of muscle damage induced by eccentric exercise and ischemia/reperfusion. Scand. J. Med. Sci. Sports., 20 (5), 748-756.

6. Maksymiv, R.V., Hudyma, A.A., \& Sydorenko, V.M. (2017). Dynamika balansu antyoksydantno-prooksydantnykh mekhanizmiv u vnutrishnikh orhanakh pid vplyvom arterialnoho dzhhuta i reperfuzii kintsivky [Dynamic of balance of antioxidantprooxidant mechanism in internal organs Under the influence of blood harnesses and limb reperfusion]. Shpytalna khirurhiia. Zhurnal imeni L.Ya. Kovalchuka - Hospital Surgery. Journal Named by L.Ya. Kovalchuk, 1, 37-44. DOI: 10.11603/24144533.2017.1.7637 [in Ukrainian].
10. Методики клинических лабораторных исследований: Справочное пособие Том 3. Клиническая микробиология. Бактериологические иследования. Микрологические исследования. Паразитологические исследования. Инфекционная имунодиагностика. Молекулярные исследования в диагностике инфекционных заболеваний / Под ред. В. В. Меньшикова. - М. : Лабора, 2009. - 880 с.

7. Kuzminskyi, I.V. (2018). Osoblyvosti zhovchovydilnoi funktsii pechinky $\mathrm{v}$ umovakh ishemichno-reperfuziinoho syndromu kintsivok, zakrytoi travmy orhaniv cherevnoi porozhnyny, uskladnenoi masyvnoiu krovovtratoiu [Features of biliary function of the liver in conditions of ischemic-reperfusion syndrome of the extremities, closed trauma of the abdominal organs, complicated by massive blood loss]. Aktualni problemy transportnoi medytsyny - Actual Problems of Transport Medicine, 4 (54), 148158 [in Ukrainian].

8. Horban, I.I., Hudyma, A.A., Maksymiv, R.V., \& Antonyshyn, I.V. (2020). Influence of two-hour tourniquets ischemia of limb and acute blood loss on systemic disorders of the body in the reperfusion period (experimental study). Wiad. Lek., LXXIII, 7, 1330-1333.

9. Levchuk, R., Pokryshko, O., Borys, R., \& Dzetsiukh, T. (2015). Vydovyi sklad ta riven obsimeninnia mikroorhanizmamy perytonealnoho eksudatu $\mathrm{v}$ ranniy period pislia modeliuvannia skeletnoi, cherepno-mozkovoi ta poiednanoi travm [Species composition and level of contamination by microorganisms peritoneal exudate in the early period after simulation skeletal, cranial and combined injuries]. Aktualni problemy transportnoi medytsyny Actual Problems of Transport Medicine, 4, 2 (42-2), 148-155 [in Ukrainian].

10. Menshikova, V.V. (Ed.). (2009). Metodiki klinicheskikh laboratornykh isledovaniy: Spravochnoye posobiye Tom 3. Klinicheskaya mikrobiologiya. Bakteriologicheskiye isledovaniya. Mikologicheskiye isledovaniya. Parazitologicheskiye isledovaniya. Infektsionnaya imunodiagnostika. Molekulyarnyye isledovaniya $v$ diagnostike infektsionnykh zabolevaniy [Methods of clinical laboratory research: Reference manual Volume 3. Clinical microbiology. Bacteriological research. Mycological research. Parasitological research. Infectious immunodiagnostics. Molecular research in the diagnosis of infectious diseases]. Moscow: Labora [in Russian]. 
I. V. STRELBYTSKA, A. V. POKRYSHKO, K. A. POKHODUN

I. Horbachevsky Ternopil National Medical University

\title{
SPECIES COMPOSITION AND LEVEL OF PERITONEAL EXUDATE CONTAMINATION BY MICROORGANISMS IN CONDITIONS OF ACUTE BLOOD LOSS COMPLICATED BY LIMB ISCHEMIA-REPERFUSION
}

\begin{abstract}
The aim of the study: to determine the species composition and level of contamination of peritoneal exudate with microorganisms in conditions of acute blood loss complicated by ischemia-reperfusion of the limb.

Materials and Methods. The experiments were performed on 96 nonlinear male rats weighing 180-200 g. All animals were divided into four groups: control and three research. In thiopental-sodium anesthesia in the first experimental group simulated limb ischemiareperfusion, in the second - acute blood loss, in the third - these injuries were combined. After 1 and 2 hours, as well as after 1, 7 and 14 days under conditions of thiopental sodium anesthesia, the experimental animals were removed from the experiment by the method of total bloodletting from the heart. The material (peritoneal smear) was taken from the lateral parts of the abdominal cavity with a single use tampon by Eurotubo (Spain). The study of the available microflora was performed by conventional bacteriological method. Results and Discussion. When modeling limb ischemia-reperfusion, acute blood loss and their combination, translocation of microorganisms takes place. It was the highest in the simulation of acute blood loss complicated by ischemia-reperfusion of the limb, the lowest - in the simulation of only ischemia-reperfusion of the limb, as evidenced by bacterial contamination of peritoneal exudate, incidence (Pi) and data on the persistence of enterobacteria in different groups. The peritoneal space of the Escherichia coli population was the first to be colonized at high concentrations, as evidenced by the high incidence of Pi for E. coli in all groups of experimental animals compared to other isolated microorganisms. Bacterial excretion rates were highest in animals with a combination of limb ischemiareperfusion and acute blood loss. Increased intestinal wall permeability with translocation of intestinal microflora is a sensitive indicator of ischemic-reperfusion syndrome and acute blood loss, which should be taken into account when developing intensive care measures.
\end{abstract}

Key words: small intestine; blood loss; ischemia-limb reperfusion; translocation of microflora.

\section{И. В. СТРЕЛЬБИЦКАЯ, А. В. ПОКРЫШКО, К. А. ПОХОДУН}

Тернопольский национальный медицинский университет имени И. Я. Горбачевского МОз Украины

\section{ВИДОВОЙ СОСТАВ И УРОВЕНЬ ОБСЕМЕНЕНИЯ МИКРООРГАНИЗМАМИ ПЕРИТОНЕАЛЬНОГО ЭКССУДАТА В УС.ЛОВИЯХ ОСТРОЙ КРОВОПОТЕРИ, ОС.ЛОЖНЕННОЙ ИШЕМИЕЙ- РЕПЕРФУЗИЕЙ КОНЕЧНОСТИ}

\begin{abstract}
Цель работы: выяснить видовой состав и уровень обсеменения микроорганизмами перитонеального экссудата в условиях острой кровопотери, осложненной ишемией-реперфузией конечности.

Материалы и методы. Эксперименты выполнены на 96 нелинейных крысах-самцах массой 180-200 г. Всех животных разделили на четыре группы: контрольную и три исследовательских. Под тиопентал-натриевым наркозом в первой опытной группе моделировали ишемию-реперфузию конечности, во второй - острую кровопотерю, в третьей - эти повреждения сочетали. Через 1 и 2 часа, а также через 1, 7 и 14 суток в условиях тиопентал-натриевого наркоза подопытных животных выводили из эксперимента методом тотального кровопускания из сердца. Материал (мазок из брюшины) забирали из латеральных частей брюшной полости одноразовым тампоном фирм Eurotubo (Испания). Исследование имеющейся микрофлоры проводили общепринятым бактериологическим методом.

Результаты исследований и их обсуждение. При моделировании ишемии-реперфузии конечности, острой кровопотери и их сочетания имеет место транслокация микроорганизмов. Она была наибольшей при моделировании острой кровопотери, осложненной ишемией-реперфузией конечности, наименьшей - при моделировании только ишемии-реперфузии конечности, о чем свидетельствуют показатели бактериального обсеменения перитонеального экссудата, встречаемости (Pi) и данные о постоянстве выделения культур энтеробактерий в разных группах. Первыми и в высоких концентрациях колонизировали перитонеальное пространство популяции кишечных палочек, о чем свидетельствовал высокий показатель встречаемости Pi для E. coli во всех группах подопытных животных, по сравнению с другими выделенными микроорганизмами. Показатели постоянства выделения бактерий были самыми высокими у животных с сочетанием ишемии-реперфузии конечности и острой кровопотери. Увеличение проницаемости кишечной стенки с транслокацией кишечной микрофлоры является чувствительным индикатором ишемически-реперфузионного синдрома и острой кровопотери, что следует учитывать при разработке мероприятий интенсивной терапии.
\end{abstract}

Ключевые слова: тонкая кишка; кровопотеря; ишемия-реперфузия конечности; транслокация микрофлоры. 